\title{
Samskabelse af
}

\section{engagement}

\section{- om fastholdelse af de studerendes deltagelse i undervisning}

\author{
Ulla Thrgersen, adjunkt, Institut for Laring og Filosofi, Aalborg Universitet
}

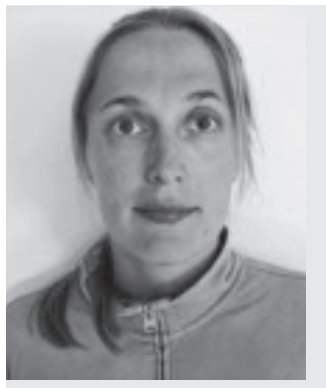

Ulla Thøgersen er ansat som adjunkt ved Institut for Uddannelse, Læring og Filosofi på Aalborg Universitet. Hun er uddannet cand.mag. i kommunikation og filosofi (200l) og ph.d. i læringsteori og filosofi (2007). Hendes forskningsinteresse er i bred forstand menneskesyn i teoridannelser inden for læring, pædagogik, kommunikation og organisation med særlig fokus på krop, følelser og motivation. Hun underviser især på Kandidatuddannelsen i læring og forandringsprocesser på Aalborg Universitet såvel som på Masteruddannelsen i læreprocesser, men har også undervisningsopgaver på en række andre uddannelser.

\section{Reviewet artikel}

Formålet med artiklen er at bidrage til en generel diskussion om motivation $i$ relation til universitetsdidaktik set inden for rammerne af en frafaldsproblematik på undervisningsniveau. Mere specifikt sigter artiklen på at nuancere forstaelsen af motivation $i$ retning af samskabelse af engagement. Det centrale argument er, at motivation ikke kun skal ses som noget allerede eksisterende - enten i form af subjektivt givne behov eller oplevede problemsituationer - en underviser kan (forsøge at) koble sig på, men underviseren har også mulighed for at tilrettelagge aktiviteter, så motivation emergerer $i$ selve samspillet mellem deltagerne $i$ undervisningen.

\section{Indledning}

En aktuel problematik på landets universiteter er knyttet til fastholdelse af studerende i deres uddannelse. En parallel problematik er frafald på undervisningsniveau, dvs. at studerende undlader at deltage $\mathrm{i}$ bestemt undervisning indlagt $\mathrm{i}$ deres uddannelse. De studerende fravælger eksempelvis bestemte kurser eller deltager ikke i det omfang kurset lægger op til. De studerendes manglende deltagelse er en kendt problematik for undervisere på kurset "Samarbejde, læring og projektstyring« (SLP) på den etårige basisuddannelse på det ingeniør-, natur- og sundhedsvidenskabelige fakultet på Aalborg Universitet. ${ }^{1}$ I forhold til SLP-kurset kan frafaldet indkredses som et legitimitetsproblem på to niveauer. Det første niveau drejer sig om kursets legitimitet i relation til et organisatorisk niveau omkring basisuddannelsen. Det kan eksempelvis handle om at underviseren er en gæst ${ }^{2} \mathrm{i}$ det faglige miljø som de studerende er en del af - og desuden at de fagpersoner, de studerende møder, f.eks. vejledere på deres projekt, ikke altid har SLP-fagligheden som en prioritet i forhold til de studerendes studieindsats. Det andet niveau drejer sig om kursets legitimitet i forhold til de studerende. Det handler om de studerendes oplevelse af mening i forhold til kursets indhold. Det kan hænge sammen med første niveau, men det kan også have med andre forhold at gøre. I forhold til SLP-kurset er det ikke sjældent, at underviseren hører formuleringen: "Jeg ved godt, hvordan man arbejder i grupper«. Der er også eksempler på studerende, som siger, at de ikke vægter kurset, fordi det er en ekstra ting ved siden af det faglige, de egentlig er her for at lære. De sidste bemærkninger nuanceres dog af udsagn fra studerende, som siger, at de ikke før har arbejdet med problemorienteret projektarbejde og derfor har brug for kursets redskaber til dette arbejde.

Den sidste nuancering tjener til at vise, at kurset har samme udfordring som universitetsuddannelse generelt, nemlig at universiteterne $\mathrm{i}$ dag optager flere studerende end førhen og står med en større diversitet $i$ forhold til studerendes forudsæetninger, forventninger og interesser. Universitetsundervisning har som udfordring at rumme disse forskelle (Rasmussen et al., 2006). Derudover peger forskning på, at universiteterne står med en anden type studerende $\mathrm{i}$ dag end tidligere. Rasmussen et al. skriver: 
"For mange studerende er uddannelse i langt hojere grad end tidligere en lystbetonet og identitetsgivende aktivitet. De studerende onsker $i$ vidt omfang selv at sammenscette deres uddannelse, så det passer til det repertoire af erfaringer og forudsatninger..."(Rasmussen et al., 2006:).

Det vil sige, at de studerende i højere grad end tidligere vælger til og fra - og desuden at studieordningens rammesætning af krav til de studerende i mindre grad er betydningsfuld i forhold til de studerendes oplevelser af egen lyst. ${ }^{3}$

Et indsatsområde $\mathrm{i}$ forhold til fastholdelse af studerende $i$ undervisning er at fă skabt en engagerende grund. Dette område behandles i universitetspædagogisk litteratur som et spørgsmål om motivation (se f.eks. Biggs \& Tang, 2007, p.31). Udfordringen er at få de studerende involveret i undervisningen, så de deltager i de aktiviteter, der kan åbne for tilsigtede læreprocesser. Et forhold i denne udfordring er at sikre de studerendes deltagelse i modsætning til frafald. Et andet forhold er at muliggøre 'deep approaches' til læring i modsætning til overfladiske tilgange (Biggs \& Tang, 2007, p.31; Ramsden, 1999). Formålet med denne artikel er at bidrage til en diskussion om motivation i relation til universitetsdidaktik set inden for rammerne af en frafaldsproblematik på undervisningsniveau. Mere specifikt vil artiklen i sin første del pege på forskellige kategorier af motivationsteorier og kort forholde sig til teoriernes implikationer $\mathrm{i}$ forhold til undervisningsplanlægning. Et sigte i den teoretiske del er at supplere eller nuancere klassiske motivationsteorier - der sætter fokus på subjektivt givne behov eller oplevede uoverensstemmelser som læringens motivationelle grund - med en begrebsdannelse rettet mod samskabelse af engagement. Det centrale argument er, at motivation ikke kun skal ses som noget, der enten allerede eksisterer før undervisningen eller ikke - og som underviseren kan forsøge at koble sig på. Motivation kan i høj grad emergere i selve samspillet mellem deltagerne i undervisningen og dermed ses som udtryk for samskabelse af engagement. Artiklens anden del giver eksempler fra min afvikling af SLP-kurset i efteråret 2009 med sigte på at samskabe et engagement, der fastholder de studerende i undervisningen.

\section{1. del. Teoretiske perspektiver på motivation}

Læring er relateret til den måde, hvorpå den enkelte deltager i undervisningen og til den mening, der er integreret i denne deltagelse. Et centralt spørgsmål for en underviser er dermed: Hvad er der på spil i de studerendes deltagelse, som kan bringe dem til læring? Teoretiske perspektiver på motivation giver forskellige svar og indebærer forskellige praktiske implikationer for planlægning og afvikling af undervisning. I det følgende præsenteres fire tilgange til motivation:
1. Motivation som udtryk for mangel

2. Motivation som udtryk for oplevet uoverensstemmelse

3. Motivation som udtryk for mening i relation til identitetsdannelse

4. Motivation som udtryk for inspiration

De første to tilgange sætter primært fokus på motivation som noget allerede eksisterende uden for undervisningens sociale samspilsrelationer, mens de to sidste tilgange i højere grad åbner for en forståelse af motivation i retning af samskabelse af engagement i selve undervisningssituationen. Ideen med kort at formidle de fire tilgange er at åbne for et nuanceret perspektiv på motivationelle fænomener - og derigennem også pege på forskellige måder at håndtere en frafaldsproblematik knyttet til de studerendes deltagelse i undervisning.

Ad 1) Klassiske motivationsteorier sætter fokus på subjektive motiver: Drifter, behov, instinkter, intentioner og målsætninger. Dette udgangspunkt ser vi blandt andet hos Maslow og McClelland, der begge betragter motivation som behovstilfredsstillelse (Maslow, 1954; McClelland, 1961). Maslow beskriver hvordan et behov melder sig som en mangeltilstand, der engagerer subjektet i en situation, der kan betyde, at manglen forsvinder, dvs. behovet tilfredsstilles. I relation til undervisning er motivation til læring dermed til stede, hvis undervisningen betragtes som middel eller mål til at tilfredsstille et eksisterende behov. Den motivationelle grund til læring er i princippet 'uden for' undervisningen selv, da motivationen knytter sig til en eksisterende, subjektiv forankret forudsætning. Med afsæt i Maslow må planlægningen af undervisning foregå i en tilstræbelse på et match mellem behov og undervisningens aktualisering af en tilfredsstillelse. Maslow taler om bestemte behov som generelt motiverer mennesket: Fysiologiske behov, behov for sikkerhed, kærlighed, anseelse og selvaktualisering (Maslow, 1954). Det samme gør McClelland med fokus på behov for accept, præstation og magt (McClelland, 1961).

Maslows begreb om behov finder vej til andre indflydelsesrige værker. I sin teori X og Y overtager McGregor f.eks. Maslows synspunkt, at mennesket er motiveret af iboende behov (McGregor, 1960). Der ud fra peger han på, at teori $\mathrm{X}$-strategier såsom kontrol og straf $\mathrm{i}$ forhold til at få andre til at handle er problematiske set i lyset af, at vi egentlig har en iboende drivkræft. McGregor foreslår derfor teori Y-strategier såsom decentralisering (selvstudium), opsætning af tydelige målsætninger for arbejdet og vejledning baseret på den forudsætning, at vi grundlæggende er motiverede. ${ }^{4}$ McGregors teori diskuteres af Biggs \& Tang $\mathrm{i}$ relation til 'klimaet' i universitetsundervisning (Biggs \& Tang, 2007, p.37ff). De argumenterer for, at det har en væsentlig betydning for læreprocessen, om underviseren betragter de studerende ud fra en teori X eller $\mathrm{Y}$ og dermed skaber et undervisningsklima baseret 
på negative forstærkere, f.eks. frygt for at fejle, eller baseret på en grundlæggende tillid til de studerendes selvmotivation. Biggs \& Tang kobler dette perspektiv til en pointe om, at motivation kan øges ud fra to parametre: Forventning om succes og værdi. I forhold til værdidimensionen diskuterer de fire kategorier:Ydre motivation koblet til forventede resultater (belønning/ straf), social motivation (anerkendelse), præstationsmotivation (styrkelse af ego) og indre motivation (en grundlæggende interesse). De fire kategorier minder om Maslows og McClellands identificering af grundlæggende behov. I lighed med deres behovskategorier handler det om, at underviseren kan koble sig på og forsøge at understøtte en eksisterende værdidimension med det formål at få motivation bragt ind i undervisningen.

Ad 2) For flere læringsteoretikere er læreprocessens udspring ikke knyttet til givne subjektive behov, men til en oplevelse af en eller anden form for uoverensstemmelse $i$ et samspil med omgivelserne. Argyris og Schön ser eksempelvis læring som en korrektion af mismatch mellem forventninger og handlinger (Argyris \& Schön, 1978; 1996). ${ }^{5}$ Inden for denne ramme kan motivation betragtes ud fra et 'eksistentielt krav' om at opretholde en overensstemmelse (match eller balance) mellem forventninger og handlinger, da selve motivationen tager form af et 'behov' til at reetablere en overensstemmelse. Det kobles til forskellige former eller niveauer for læring afhængigt af reetableringens karakter, f.eks. single-loop og double-loop. Dette teoretiske perspektiv kan primært bruges til at forstå læring i relation til oplevede problemer i praksis. I forhold til planlægning af undervisningsaktiviteter anvendes perspektivet primært til at iværksætte interventioner i relation til identificerede mismatch-situationer. Det er en mere vanskelig opgave at sætte perspektivet i spil i forhold til planlægning af universitetsundervisning. Hvis problemet (et mismatch) ikke allerede er til stede for de studerende som et grundlag for deres motivation, så kan underviseren forsøge at motivere den studerende i kraft af at skabe oplevelsen af et mismatch, der kan skabe et behov for genopretning af match. Eksempelvis kan man forestille sig casearbejde som knytter an til dette perspektiv, hvor en case kan simulere et mismatch (et dilemma), som de studerende kan overtage og arbejde med.

Ad 3) I sin læringsteori peger Wenger på en anden grund til motivation end behov og uoverensstemmelse, når han taler om læring som en social forankret forhandling af mening baseret på reifikation og deltagelse (Wenger, 1998). Hans definition af mening kan ses som et forsøg på at finde en motivationel grund i læring, uden at han dog anvender denne betegnelse. Han taler i stedet om engagement koblet til den socialt indlejrede oplevelse af mening. Wenger definerer mening som "our ability to experience the world and our engagement in it as meaningful."(Wenger, 1998, p.4). Denne defini- tion kan kritiseres for at være cirkulær: Mening er det meningsfulde. Det gør det vanskeligt at anvende dette perspektiv i relation til planlægning af undervisning: Hvordan understøtter vi mening gennem oplevelsen af mening? Et svar kan indkredses $i$ et andet af hans begreber: Identitet. Ifølge Wenger finder oplevelsen af mening sted i relation til identitetsprocesser, der er forbundet med vores deltagelse i fællesskaber. Wenger ser identitet som noget, der konstant 'samskabes' i sociale fællesskaber som udtryk for den enkeltes medlemskab og deltagelse (Wenger, 1998, p.169ff). Undervisning kan ses som led i identitetsprocesser på to niveauer. For det første er de studerende i færd med at samskabe identiteter som studerende i forlængelse af deres deltagelse i undervisningen. For det andet er undervisning også kendetegnet ved at være en åbning til fremtidige mulige fællesskaber - og der er dermed fokus på identitetsprocesser rettet frem mod at være færdiguddannet og træde ud i en anden sammenhæng (se også Chappell et al., 2003). I forhold til undervisningsplanlægning er det muligt for underviseren at gå eksplicit ind i disse identitetsprocesser. Lidt populært udtrykt kan man tale om, at 'de studerende skal kunne se sig selv i undervisningen', men i stedet for at tænke det som udtryk for, at underviseren kobler sig på en allerede given identitet (i stil med et givent behov eller et eksisterende problem), så handler det om, at underviseren er med til at samskabe identitetsprocesser og derigennem træder aktivt ind $\mathrm{i}$ en meningsforhandling rettet mod at skabe et engagement. Dette perspektiv åbner dermed med større tydelighed end de to først beskrevne motivationsforståelser for en forståelse af motivation som noget, der kan samskabes inden for rammerne af en social praksis.

Ad 4) Et andet perspektiv på motivation er knyttet til et begreb om inspiration (Thøgersen, 2010). I forhold til undervisning kan inspiration præciseres som en begivenhed, hvor man føres ud over sig selv og oplever en mening/en retning ${ }^{6}$, der ikke var ens egen før undervisningens begyndelse. Inspiration kommer af det latinske 'inspiro' - at indånde. Det peger på et responsivt element. I inspirationen tager man noget ind, der ikke var ens eget før. Med inspirationen følger en 'expiration', en udånding, hvor inspirationen tager form som en mening, en retning, hvorigennem det nye, der er taget ind, udtrykkes. Begrebet om inspiration peger på et muligt samskabende element $\mathrm{i}$ undervisning, hvor engagement vækkes i kraft af deltagernes måde at være sammen på og respondere på hinanden. Dette engagement er knyttet til et spontant emotionelt grundlag og udtrykker sig som en åbning for noget, der ikke allerede eksisterer. Denne teoretiske forståelse betyder to ting set i sammenhæn med en klassisk motivationsforståelse knyttet til behov. For det første sker der et skift i fokus fra iboende subjektive forhold til en samskabende relation som grund for et engagement. For det andet sker der et skift i fokus fra det allerede 
eksisterende til det konstant emergerende - og det medfører, at undervisningen ses som en proces, hvor et motiv 'bag' deltagelsen ikke behøver at være der på forhånd, men et engagement fremkommer undervejs som et umiddelbart emergerende fænomen knyttet til selve situationen og deltagernes respons på hinanden. For underviseren betyder denne tankegang, at motivation ikke primært skal opdages og matches, men at det konstant skal samskabes.

Umiddelbart indeholder de fire tilgange til motivation alle noget centralt $\mathrm{i}$ forhold til forståelsen af motivationelle fænomener. Vi har alle forskellige behov, som trækker os i bestemte retninger.Vi kan støde på overraskelser i vores samspil med omgivelserne og derigennem blive ud- eller opfordret til at ændre en forståelse eller en måde at handle på. Desuden virker det plausibelt, at vi i den sociale verden konstant forhandler mening og identitetsprocesser såvel, som vi kan inspirere hinanden. Pointen med denne artikel er på den måde ikke at afvise eksistensen af forskellige former for motivationelle fænomener men at henlede opmærksomheden på motivationsfænomener, der overskrider en forståelse af motivation som noget, der enten er givet eller ikke-givet med subjektive dispositioner eller vilkår. Perspektivet for en sådan overskridelse finder vi både hos Wenger og $i$ et begreb om inspiration, hvor motivation primært betragtes som et emergerende fænomen, der samskabes inden for rammerne af den konkrete (sociale) praksis. Denne overskridelse åbner for et blik på underviserens muligheder for didaktisk at planlægge sin undervisning $i$ et sigte på at samskabe engagement i selve undervisningen. I dette blik kan de studerende ikke partout opdeles i to grupper: De gode og de dårlige, hvor de gode er de allerede engagerede, og de dårlige mangler engagement. Blikket føres væk fra motivation som noget, der allerede er (eller ikke er) iboende den enkelte studerende - og i stedet er fokus på underviserens muligheder for aktiviteter rettet mod at samskabe engagement.

\section{2. del. Et undervisningsforløb}

I denne del vil jeg give konkrete eksempler på, hvordan jeg selv har arbejdet ud fra et begreb om samskabelse af engagement med det formål at fastholde de studerende i et undervisningsforløb. Denne del skal primært ses som praksisformidling, der knytter an til de teoretiske overvejelser fra første del. I planlægningen af SLP-kurset for Arkitektur og Design-faggruppen (140 studerende) i efteråret 2009 var det mit sigte at arbejde ud fra et begreb om samskabelse af engagement, især i relation til Wengers perspektiv på samskabelse af identitetsprocesser såvel som ud fra et begreb om inspiration. Som beskrevet indledningsvis er frafald en kendt problematik for kurset, og det rejser dermed problemstillingen: Hvordan kan jeg fastholde de studerende, så de for det første møder frem og for det andet deltager $i$ aktiviteterne, der åbner for de tilsigtede læreprocesser? Jeg vil her præsentere eksempler fra to kursusgange: Den første, introducerende to-timers undervisning $\mathrm{i}$ P0 og den første, fire-timers kursusgang i P1-forløbet, som fandt sted dagen efter gruppedannelse. ${ }^{7}$ Begge kursusgange fandt sted i traditionelle auditorier med alle studerende samlet. I planlægningen af begge kursusgange anvendte jeg power-points, da det gav mulighed for at fastholde billeder og væsentlige pointer.

\section{Introducerende kursusgang}

I denne kursusgang viste min forste slide fire billeder (Utzon-centret i Aalborg, en digital mus, A\&D-studerende i grupperum og sluseholmen i København) sammen med spørgsmålet: Hvad har disse ting til fælles?

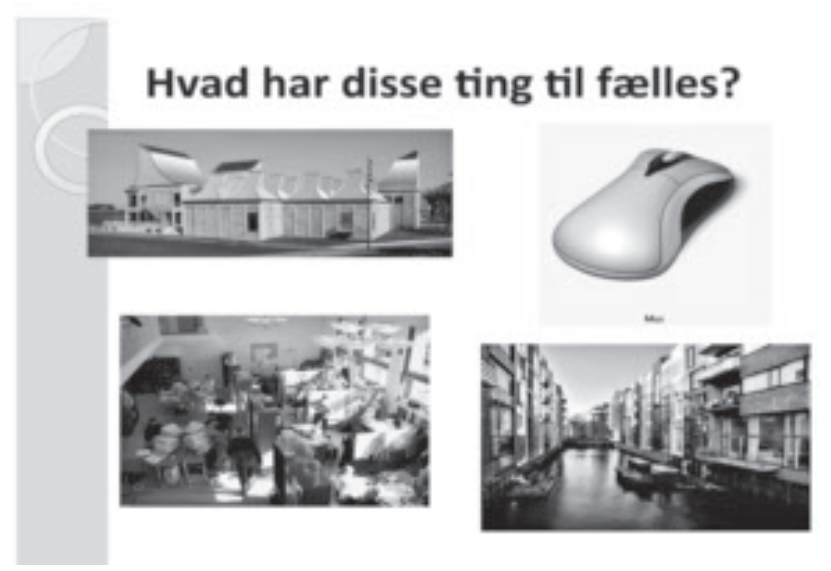

Tanken var at knytte tre elementer sammen i dialog med de studerende: De studerendes hverdag, hvor projektarbejdet fylder meget, deres fremtidige udsigter til at fungere som arkitekter og designere og endelig undervisningens faglige indhold. I afviklingen pegede de studerende på forskellige ting. F.eks. kom et par studerende ind på, at alle motiverne udtrykker projekter. Disse svar førte mig til næste slide med et muligt svar: Samarbejde, læring og projektstyring. De to slides gav mig mulighed for sammen med de studerende at samskabe en pointe om, at kursets faglige indhold ikke kun er relevant i hverdagen som studerende, men også udgør vigtige kompetencer i arkitekt- og designfaget.

Den indledende dialog blev afsæt til yderligere sammenkoblinger mellem kursets indhold og faget set $\mathrm{i}$ en anknytning til identitetsprocesser. Jeg havde fundet udsagn om mulig beskæftigelse for færdiguddannede kombineret med udsagn fra hjemmesider (Dansk Design Center, et arkitektfirma og byggeri.dk) hvor vigtigheden af samarbejde, læring og projektstyring i relation til arkitektur og design fremgik. Desuden havde jeg fundet to 'fortællinger' $i$ studieguiden af tidligere A\&D-studerende. De formulerer sig om at være i arbejde efter endt uddannelse og forholder sig til hvad uddannelsen har givet dem. Herunder angiver de, at de projektmetodiske kompetencer er meget væsent- 
lige. Denne fortælling ledte frem til et andet vigtigt element igennem kurset: Medvirken af en hjælpelærer fra A\&D-miljøet. Jeg havde inden kurset bedt ham være ambassadør for kurset og bedt ham forberede et oplæg med eksempler, der kunne betone vigtigheden af samarbejde, læring og projektstyring i forhold til faget. Flere spørgsmål om hans erfaringer blev undervejs rettet til hjælpelæreren, såvel som han undervejs supplerede mine oplæg med en konkret relatering til faget og til de studerendes projektarbejde på $\mathrm{P} 0$ (hvor han fungerede som vejleder for flere af grupperne). Tankegangen bag inddragelsen af hjælpelæreren var muligheden for at stille et spejl op for de studerende og derigennem også skabe en legitimitet i kursets indhold set $\mathrm{i}$ forhold til faget såvel som at koble sig aktivt på identitetsprocesser. Efter kursusgangen sagde en studerende: "Det er seriøst det her, altså det er en vigtig del af, hvad vi skal kunne, når vi er fardiguddannede."

Disse aktiviteter er eksempler på en social forankret forhandling af mening knyttet til de studerendes identitetsprocesser, hvor denne forhandling er lagt eksplicit ind $i$ undervisningen. Sigtet er at skabe mening $i$ kursets indhold ved at indgå i en identitetsproces med de studerende og i denne proces forhandle ud fra standpunktet, at SLP-fagligheden er noget centralt både i forhold til at 'at være studerende' og 'at blive færdiguddannede arkitekter og designere'. I denne proces forudsættes ikke en bestemt identitetsforestilling hos de studerende, dvs. at der ikke er tale om at koble sig på en given identitet, snarere at koble sig på et givent studievalg og derudfra forhandle mening her og nu. I denne proces er det også centralt med muligheden for inspiration, som hentes $\mathrm{i}$ de fortællinger fra tidligere studerende, der bringes ind i undervisningsrummet.Ved at læse, opleve og høre færdiguddannede, så skabes der begivenheder, hvor det er muligt at blive ført ud over sig selv og sit eget perspektiv og opleve en retning, der ikke var ens egen før selve undervisningen. Det vil sige, at det er muligt at tage noget nyt ind i en samskabelse af engagement.

I afslutningen af kursusgangen bad jeg de studerende om at skrive to ting på en post-it:

\section{Afslutning}

Tag en gul post-it og lav en streg, så den er delt $i$ to rum:

1. For at få projektprocessen til at fungere bedst muligt er det vigtigt...

2. For at få projektprocessen til at fungere bedst muligt kan jeg...
De studerende satte efterfølgende deres post-it på papir hængt op ved indgangen. Tanken var at det gav de studerende mulighed for at sætte ord på, hvad de anså for vigtigt (og meningsfuldt) i relation til projektet, og det gav mig mulighed for i planlægning af senere kursusgange at starte en meningsforhandling fra dette perspektiv. Jeg modtog et fuldtalligt antal gule sedler og de fleste med mange ord.

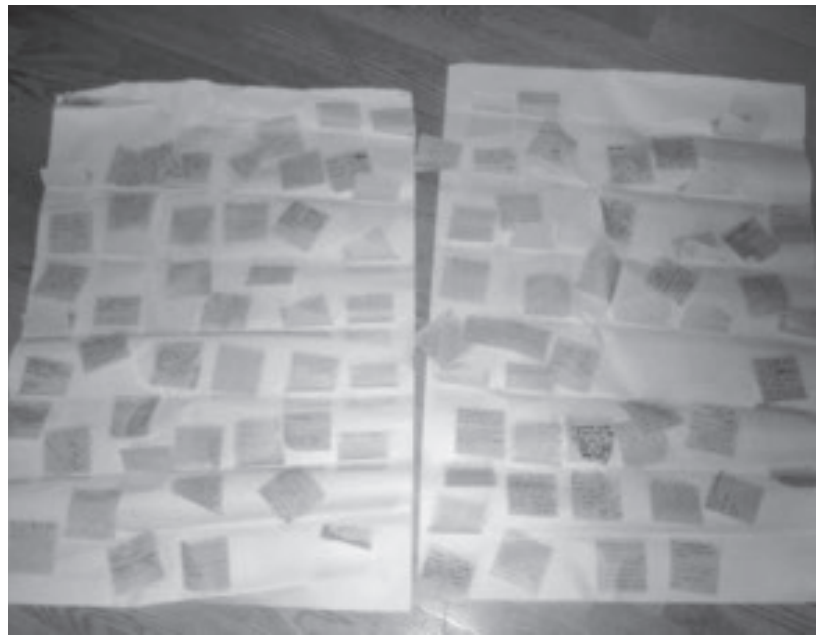

\section{Kursusgang om gruppesamarbejde}

Første kursusgang i $\mathrm{P} 1$-forløbet havde fokus på gruppesamarbejde. Jeg valgte at placere kursusgangen dagen efter gruppedannelse, da det var en mulighed for at koble sig på en umiddelbar optagethed fra de studerendes side: At få skabt nogle rammer for den nye gruppe. I selve kursusgangen spillede de gule sedler en central rolle.Jeg erindrede dem indledningsvis om de to spørgsmål fra første kursusgange og viste dem tre slides kun fyldt med deres egne ord med det formål, at de kunne spejle sig i og lade sig inspirere af hinandens forståelser. Jeg bad dem om at læse dem igennem uden at jeg kommenterede - da det væsentlige her var at de 'hørte' hinanden og de opfordringer, som sedlerne indeholdt i forhold til at få skabt en god projektproces. Efterfølgende bad jeg dem diskutere hvad der kendetegner en velfungerende gruppe ud fra forskellige billeder:

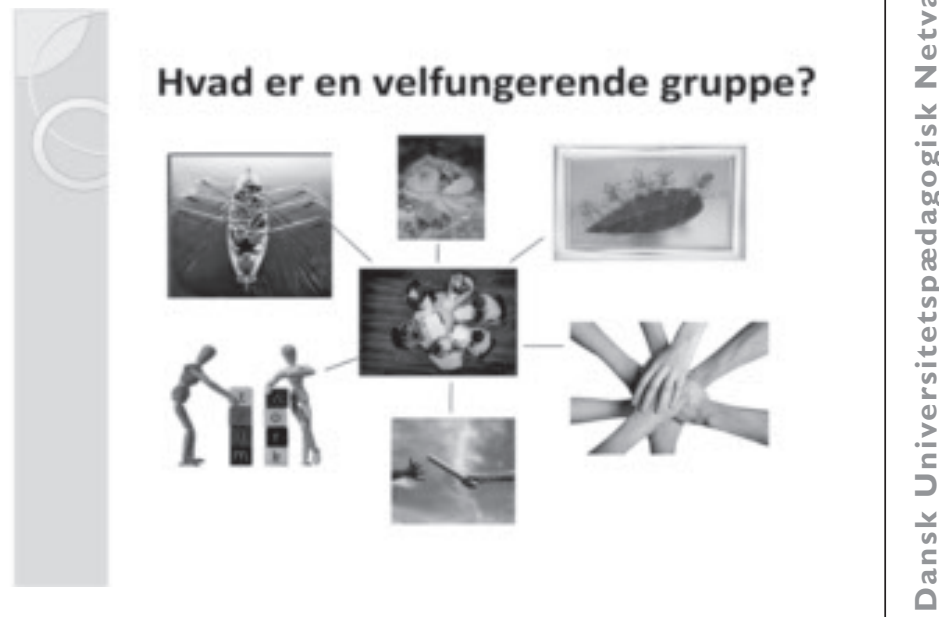


Jeg gik efterfølgende videre til teoretiske fremstillinger af den gode gruppe, hvor hver fremstilling var spejlet $i$ et citat fra en gul seddel. Tankegangen var at skabe en relation mellem deres virkelighed lige nu, hvor de var indtrådt $i$ et gruppesamarbejde, de studerendes forståelse af et godt gruppearbejde og de teoretiske fremstillinger, der var en del af kursets faglige grundlag. Denne relation var udtryk for en forhandling af mening med de studerende, hvor præmissen var at tydeliggøre og fastholde vigtigheden af kursets faglige indhold $\mathrm{i}$ relation til den praksis de er en del af som studerende. Vigtigheden forudsættes ikke allerede oplevet af de studerende, men tankegangen bag planlægningen var, at en oplevelse af vigtighed skal emergere $i$ undervisningsaktiviteterne, især i forlængelse af en gensidig inspiration og opfordring fra deres egne ord på sedler og i diskussioner, hvor selve koblingen til deres hverdag i projektgruppen var central. I den forstand kombinerede undervisningen egentlig et perspektiv på en given situation eller praksis de studerende befandt sig i (noget allerede forudsat), med et blik på muligheden for at inspirere og skabe oplevelser af mening i relation til den givne situation, så kurset dermed oplevedes som meningsfuldt.

\section{Afslutning}

Den væsentligste pointe, som det er denne artikels interessefelt at trække frem, er på den ene side et teoretisk opgør med tankegangen om selvmotiverede studerende, som allerede har (eller ikke har) bestemte behov, en undervisning kan forsøge at koble sig på, og på den anden side en nuancering af motivation $i$ retning af samskabelse af engagement. Det er denne pointe første teoretiske del præsenterer. Anden del giver eksempler på undervisningsplanlægning, der har haft til formål at samskabe engagement. Fremstillingen af de konkrete eksempler er baseret på særlige metodiske forhold. Fokus er især på de planlægningsmæssige sider af undervisningen, derunder begrundelser for aktiviteterne i lyset af forhandling af mening og inspiration. Som dokumentation indeholder artiklen eksempler fra slides såvel som beskrivelser af forhold i planlægningsfasen. Disse eksempler kan dog ikke sige noget om de studerendes faktiske deltagelse i undervisningen. I selve afviklingen af undervisningen valgte jeg ved hver kursusgang at notere fremmøde ned, dvs. at forholde mig til hvor mange studerende, der var mødt frem såvel som jeg efter hver kursusgang noterede mine oplevelser ned i relation til de studerendes deltagelse i diskussioner/opgaver, anden respons og kommentarer etc. Der er derfor grundlag for at konkludere, at fremmødet var højt. Til alle kursusgange ${ }^{8}$ har der været næsten et fuldtalligt hold (ca. 130 studerende). De studerende faldt heller ikke fra i løbet af undervisningsforløbet, men antallet af studerende, som deltog $i$ hele undervisningstiden, var konstant. Det vil sige at frafald forstået som manglende fremmøde blev undgået. I forhold til de studerendes deltagelse i aktiviteterne, så fremgår det af mine notater, at de studerende var meget aktive undervejs. De stillede spørgsmål, gav svar og diskuterede. Derudover var der en vis synlighed i de aktiviteter de deltog i: De gule post-it's, tidsplaner og samarbejdsaftaler - og det var muligt for mig at se, at de blev udformet. Umiddelbart kan det derfor dokumenteres, at frafaldsproblematikken blev forhindret, såvel som de studerende gik i gang med de opgaver kurset indeholdt. Det kan dog ud fra den eksisterende empiri være vanskeligt at udtale sig om hvorfor og tillægge de enkelte aktiviteter og den underliggende motivationsforståelse en særlig betydning i den forbindelse. Det vil kræve en mere udfoldet undersøgelse knyttet til de enkelte studerende og deres oplevelser. Dog kan det antages ud fra artiklen - også på teoretisk grundlag - at der kan være en central pointe i et nuanceret didaktisk blik på motivation i undervisningen, herunder en forståelse af muligheden for at samskabe engagement $i$ undervisningen.

\section{Referencer}

Argyris, Chris and Donald A. Schön (1978). Organizational Learning. A Theory of Action Perspective. New York: Addison-Wesley.

Argyris, Chris and Donald A. Schön (1996). Organizational Learning 2: Theory, Method and Practice. New York: Addison-Wesley.

Bateson, Gregory (1998). De logiske kategorier for læring og kommunikation. In: Mads Hermansen (1998): fra læringens horisont. Århus: Klim.

Biggs, John and Catherine Tang (2007). Teaching for Quality Learning at University. Berkshire, England: Open University Press, McGraw-Hill Education.

Chappell, C., C. Rhodes, N. Solomon, M. Tennant and L. Yates (2003): Reconstructing the Lifelong Learner. Pedagogy and Identity in Individual, Organisational and social change. London: RoutledgeFalmer.

Maslow, Abraham H. (1954). Motivation and Personality. New York: Addison Wesley.

McClelland, David C. (1961). The Achieving Society. Princeton:Van Nostrand.

McGregor, Douglas (1960). The Human Side of Enterprise. New York: McGraw-Hill.

Mezirow, Jack (2000). Transformativ læring. In: Illeris, Knud (red.) (2000). Tekster om laring. Roskilde: Roskilde Universitetsforlag.

Piaget, Jean (2000). Ligevagtsbegrebets rolle i psykologien In: Illeris, Knud (red.) (2000): Tekster om laring. Roskilde: Roskilde Universitetsforlag.

Ramsden, Paul (1999). Strategier for bedre undervisning. København: Gyldendal.

Rasmussen, Jens et al. (1996). Kvalitet $i$ undervisning. København: Ministeriet for Videnskab, Teknologi og Udvikling.

Thøgersen, Ulla (2010). Coaching som loeringsrum $i$ organisationer: begar og inspiration. In: Laursen, Erik, Jakob Nørlem og Ulla Thøgersen (red.) (2010): Coaching og organisationer: Ledelse, magt og laring. København: Hans Reitzels Forlag.

Wenger, Etienne (1998). Communities of Practice. Learning, Meaning and Identity. Cambridge: Cambridge University Press. 


\section{Noter}

1 På basisuddannelsen arbejder de studerende i grupper med problemorienteret projektarbejde - og de har desuden en række kurser der understøtter projektarbejdet såvel som den specifikke faglighed. Alle faggrupper deltager i SLP-kurset, som omfatter følgende emner: Samarbejde inkl. gruppedynamik og kommunikation; konflikthåndtering; læring; problemorientering; projektplanlægning inkl. projektstyring og -ledelse; strukturering af viden og skriftlig og mundtlig formidling af projektresultater og - processer. Kurset har aktiviteter spændt ud over hele basisåret. Kursets formål er at støtte de studerende teoretisk og praktisk i udførelsen af problemorienteret projektarbejde i grupper samt at skabe rammer for, at de studerende kan reflektere over egen og gruppens læring.

2 Med gæst menes der her, at underviseren kommer fra et andet institut og fagligt miljø, end uddannelsen formelt er tilknyttet.

3 I forbindelse med afvikling af SLP-kurset i foråret og efteråret 2009 har jeg flere gange spurgt de studerende, om de har været inde at læse studieordningen (som kan findes elektronisk på intranettet) - og knap en håndfuld af 140 studerende bekræftede dette.

4 McGregors pointer er tænkt ind i arbejdslivet i spørgsmål om management, men da de baserer sig på et grundlæggende menneskesyn, kan de kobles til undervisning og underviserens mulighed for at arbejde med motivation.

5 Andre læringsteorier, som vægter motivation som udtryk for uoverensstemmelse, finder vi eksempelvis hos Mezirow, der taler om et desorienteringsdilemma som afsæt for en transformativ læring (Mezirow, 2000) - eller i systemisk orienterede teorier, hvor læring initieres i feedback fra omgivelserne og som en form for forstyrrelse og korrektion (se f.eks. Bateson, 1998). Også Piaget kan med sit begreb om ekvilibrium placeres inden for denne overskrift: Menneskelivet er rettet mod ligevægt i samspillet med omgivelserne, og læring er udtryk for den udlignende aktivitet, der genetablerer en ligevæegt i en assimilativ og akkomodativ proces (Piaget, 2000).

6 Det franske ord "sens" - som kan betyde både mening og retning - udnytter på en meget præcis måde, at mening også er en retning i tilværelsen. Denne dobbeltbetydning understreger, at man i en meningsoplevelse også stiller sig på en bestemt måde i tilværelsen og derigennem skaber en bestemt retning for tilværelsen. En meningsoplevelse skal ikke ses isoleret, men må netop ses i en temporal forstand: Det er med til at skabe et tilværelsesforløb.

7 Efterårets kursus blev planlagt med to kursusgange under et P0-forløb (pilotprojekt-periode over de første tre uger i september) og fem kursusgange under P1-forløb (deres 1. semester projekt som løber fra begyndelsen af oktober frem til aflevering i december og eksamen i januar).

8 Jeg blev sygemeldt under forløbet på grund af svære graviditetsgener og var derfor ikke med til de to sidste kursusgange i P1. Jeg er vendt tilbage som underviser under de samme studerendes P2-forløb og til første kursusgang i P2-forløbet gennemført i denne uge (02.02.10) var der igen fuldtalligt hold. 